\title{
Nitrification in Pine Tree Substrate Is Influenced by Storage Time and Amendments
}

\author{
Linda L. Taylor ${ }^{1}$, Alexander X. Niemiera, and Robert D. Wright \\ Department of Horticulture, Virginia Polytechnic Institute and State \\ University, 301 Saunders Hall, 0327, Blacksburg, VA 24061
}

\section{Gregory K. Evanylo and Wade E. Thomason \\ Department of Crop and Soil Environmental Sciences, Virginia Polytechnic Institute and State University, Blacksburg, VA 24061}

Additional index words. loblolly pine, Pinus taeda, most probable number, marigold, Tagetes erecta 'Inca Gold', nitrate, ammonium, ammonium-N to nitrate-N ratio, $\mathrm{pH}$

\begin{abstract}
Pine tree substrate (PTS), for container plant production, is a relatively new alternative to the commonly used pine bark and peat substrates. Fertility management requires knowledge of nitrogen transformations in this new substrate. The objective of this study was to document the occurrence of nitrification in PTS and to determine if nitrification and density of nitrifying microorganisms are affected by substrate storage time and lime and peat amendments. Pine tree substrate was manufactured by hammermilling chips of $\approx 15$-year-old loblolly pine trees (Pinus taeda L.) through two screen sizes, $4.76 \mathrm{~mm}$ (PTS) and $15.9 \mathrm{~mm}$ amended with peat (3PTS:1 peat, v:v, PTSP). Pine tree substrate and PTSP were amended with lime at five rates and a peat-perlite mix (4 peat: 1 perlite, v:v, PL) served as a control treatment for a total of 11 treatments. Substrates were prepared, placed in plastic storage bags, and stored on shelves in an open shed in Blacksburg, VA. Subsamples were taken at 1, 42, 84, 168, 270, and 365 days after storage. At each subsampling day, each substrate was placed into 12 1-L containers. Six of the 12 were left fallow and six were planted with 14-day-old marigold (Tagetes erecta $\mathrm{L}$. 'Inca Gold') seedlings; all containers were placed on a greenhouse bench. Substrates were also collected for most probable number (MPN) assays for nitrifying microorganism quantification. Substrate solution $\mathrm{pH}$, electrical conductivity (EC), ammonium-N $\left(\mathrm{NH}_{4}-\mathrm{N}\right)$, and nitrate-N $\left(\mathrm{NO}_{3}-\mathrm{N}\right)$ were measured on fallow treatments. Marigold substrate solution $\mathrm{pH}, \mathrm{EC}, \mathrm{NH}_{4}-\mathrm{N}$, and $\mathrm{NO}_{3}-\mathrm{N}$ were measured after 3 weeks of marigold growth. Nitrate-N was detected in fallow containers at low concentrations $\left(0.4\right.$ to $\left.5.4 \mathrm{mg} \cdot \mathrm{L}^{-1}\right)$ in PTS in all limed treatments at all subsampling days, but in the non-limed treatment, only at Days 270 and 365 . Nitrate-N was detected in the fallow containers at low concentrations $\left(0.7\right.$ to $\left.13.7 \mathrm{mg} \cdot \mathrm{L}^{-1}\right)$ in PTSP in the 4 - and $6-\mathrm{kg} \cdot \mathrm{m}^{-3}$ lime rates at all subsampling days. Nitrite-oxidizing microorganisms were present in PTS at all subsampling days with the highest numbers measured at Day 1. Ammonium-to-nitrate ratios for the marigold substrate solution extracts for both PTS and PTSP decreased as pH increased. This study shows that nitrifying microorganisms are present and nitrification occurs in PTS and PTSP and is positively correlated to substrate pH.
\end{abstract}

Nitrification, the biological oxidation of reduced forms of nitrogen $(\mathrm{N})$ to nitrate $\left(\mathrm{NO}_{3}{ }^{-}\right)$, affects the fertilizer management of nursery and greenhouse crop production. In general, plants grow best in a combination of $\mathrm{NH}_{4}-\mathrm{N}$ and $\mathrm{NO}_{3}-\mathrm{N}$ (Barker and Mills, 1980). The extent of nitrification in container substrate

Received for publication 14 Sept. 2012. Accepted for publication 7 Nov. 2012.

The research was funded in part by the Virginia Agricultural Council and the Virginia Nursery and Landscape Association.

Use of trade names does not imply endorsement of the products named nor criticism of similar ones not mentioned.

This article is a chapter of a submitted dissertation by Linda L. Taylor for the degree of Ph.D. in Horticulture.

${ }^{1}$ To whom reprint requests should be addressed; e-mail1ltaylor@vt.edu. in most soils, is carried out by two distinct groups of chemolithotrophic bacteria, bacteria that derive their energy from oxidizing inorganic compounds and fix $\mathrm{CO}_{2}$ to produce organic carbon. Ammonia-oxidizing bacteria (AOB) oxidize $\mathrm{NH}_{4}^{+}$to nitrite $\left(\mathrm{NO}_{2}^{-}\right)$while nitrite-oxidizing bacteria oxidize $\mathrm{NO}_{2}^{-}$to $\mathrm{NO}_{3}{ }^{-}$. Ammonia-oxidizing bacteria grow in a $\mathrm{pH}$ range of 5.8 to 8.5 and have growth optima in the range of 7.5 to 8.0 (Prosser, 1989). The generally accepted reason for this sensitivity is that $\mathrm{pH}$ determines the proportions of $\mathrm{NH}_{4}^{+}$and $\mathrm{NH}_{3}$ present. The $\mathrm{pKa}$ value of the $\mathrm{NH}_{4}^{+} / \mathrm{NH}_{3}$ pair is 9.25 ; thus, $\mathrm{NH}_{4}{ }^{+}$and $\mathrm{NH}_{3}$ will be in equal proportions at $\mathrm{pH}$ 9.25. There will be more $\mathrm{NH}_{4}{ }^{+}$than $\mathrm{NH}_{3}$ below $\mathrm{pH} 9.25$ and the converse will occur above $\mathrm{pH}$ 9.25. Ammonia (the actual substrate for the oxidizing enzyme) passively diffuses into bacterial cells, but $\mathrm{NH}_{4}^{+}$transport into cells is energy-dependent and, once inside, must be deprotonated for use as substrate (Prosser, 1989).

A wide variety of heterotrophic fungi and bacteria can oxidize $\mathrm{NH}_{3}$ or reduced $\mathrm{N}$ from organic compounds to hydroxylamine, $\mathrm{NO}_{2}{ }^{-}$, and $\mathrm{NO}_{3}{ }^{-}$. No energy is derived from this conversion and rates are generally much lower than autotrophic nitrification (Prosser, 1989). This heterotrophic pathway is though to occur in some acid forest soils (Brierley and Wood, 2001; Lang and Jagnow, 1986).

Nitrification has been verified in peat (Elliott, 1986) and pine bark (Niemiera and Wright, 1986b) substrates, two commonly used substrates in the greenhouse and nursery industries. Studies with these substrates have shown nitrification to be sensitive to $\mathrm{pH}$, temperature, and concentration and form of supplied N. Nitrification rate increased with increasing $\mathrm{pH}$ (Niemiera and Wright, 1986a; Vetanovetz and Peterson, 1990) and with increasing temperature (Niemiera and Wright, 1987b). However, Walden and Wright (1995) found that temperatures greater than $46{ }^{\circ} \mathrm{C}$ had a negative impact on nitrification in a pine bark medium. Nitrification rate increased with increasing $\mathrm{NH}_{4}{ }^{+}$fertilizer concentration in pine bark (Niemiera and Wright, 1987a) In peat-based substrate, nitrification activity was greater when a $1 \mathrm{NH}_{4}-\mathrm{N}: 3 \mathrm{NO}_{3}-\mathrm{N}$ ratio was used than with either a $1: 1$ or a $3: 1$ ratio (Lang and Elliott, 1991).

Preliminary studies (L. Taylor, unpublished data) showed that nitrite-oxidizing microorganisms occur in recently manufactured and aged PTS, a relatively new alternative to pine bark and peat-based substrates (Wright and Browder, 2005; Wright et al., 2008), but nitrification in PTS has not been documented. Pine tree substrate is manufactured from trunks of $\approx 15$-year-old loblolly pine trees (Pinus taeda L.) by chipping and hammermilling to a desired particle size. Like with other substrates, PTS is stored by manufacturers and growers for later sale or use. Recently manufactured PTS has a $\mathrm{pH}$ value within the recommended range for soilless substrates, 5.4 to 6.5 (Nelson, 2003), but $\mathrm{pH}$ decreases with storage time (Taylor et al., 2012). Pine tree substrate is often amended 
with peat (to improve water retention and cation exchange capacity) and, consequently, needs lime addition to increase substrate $\mathrm{pH}$ because of the acidifying nature of peat (Jackson et al., 2009). The objective of this study was to determine if nitrification occurs in PTS and PTS amended with peat and how nitrification and the density of nitrifying microorganisms are influenced by storage time and lime amendment.

\section{Materials and Methods}

Preparation of substrates. Approximately 15 -year-old loblolly pine trees growing in Blackstone, VA, were harvested and delimbed on 16 Apr. 2009 and chipped on 21 Apr. 2009 with a Bandit chipper (Model 200; Bandit Industries, Inc., Remus, MI). Resulting pine chips were then passed through a hammermill (Meadow Mills, Inc., North Wilkesboro, NC) on 23 and 24 Apr. using two screen sizes, $4.76 \mathrm{~mm}$ and $15.9 \mathrm{~mm}$. The PTS produced with the 4.76-mm screen was used for a $100 \%$ PTS and the PTS milled with the larger screen size was amended with peat (PTSP; Premier Tech, Quebec, Canada; 3 PTS:1 peat, v:v). Initial air space (AS; \% vol) and container capacity (CC; \% vol) for PTS produced with the $4.76-\mathrm{mm}$ screen size have been reported as $36.5 \%$ and $50.5 \%$, respectively; initial AS and CC for PTSP produced with a $15.9-\mathrm{mm}$ screen size have been reported as $34.1 \%$ and $53.1 \%$, respectively (Jackson et al., 2010). These values are within or near the recommended ranges $(10 \%$ to $30 \%$ for AS and $45 \%$ to $65 \%$ for CC; Yeager et al., 2007) for substrates used in container plant production. Values for $\mathrm{pH}$ and cation exchange capacity (CEC) for PTS and PTSP and carbon-to-nitrogen ratio $(\mathrm{C}: \mathrm{N})$ for PTS are given in the Results and Discussion section of this article.

A 4 peat: 1 perlite substrate (v:v), similar to a conventional substrate for greenhousegrown crops in terms of waterholding capacity and air porosity, was included as a control. Both PTS and PTSP were amended with pulverized dolomitic limestone (Pro pulverized limestone; Old Castle Stone Products, Atlanta, GA; calcium carbonate equivalency of $95 \%$ ) at the rates of $0,1,2,4$, or $6 \mathrm{~kg} \cdot \mathrm{m}^{-3}$ for a total of 10 treatments; PL was amended with $6 \mathrm{~kg} \cdot \mathrm{m}^{-3}$ pulverized dolomitic limestone. Lime rates were chosen to ensure that $\mathrm{pH}$ of PTS and PTSP would be maintained, at least in one treatment, at an optimal $\mathrm{pH}$ for nitrification over the intended 365-d study period. All 11 substrate treatments were amended with $0.6 \mathrm{~kg} \cdot \mathrm{m}^{-3}$ calcium sulfate $\left(\mathrm{CaSO}_{4}\right.$; Espoma Organic Traditions, Millville, NJ), which has been shown to improve growth of herbaceous species in PTS (Saunders et al., 2005). After preparation, each substrate was placed in $85-\mathrm{L}$ perforated plastic bags and stored on shelves in an open shed in Blacksburg, VA, for 365 d. Monthly high and low temperatures were recorded and average daily temperatures were calculated (Table 1).

Subsampling. At Days 1, 42, 84, 168, 270, and 365 , substrate subsamples of each treatment were taken from bags. Subsamples were used to fill 121 -L plastic containers. Six containers were left fallow and six were planted with $\approx 14$-d-old marigold (Tagetes erecta L. 'Inca Gold') seedlings grown in a 144-cell plug tray using Fafard Superfine Germinating Mix (Conrad Fafard, Inc., Agawam, MA). Substrate was also collected for MPN studies that were initiated 2 to $3 \mathrm{~d}$ after subsampling.

Fallow containers. Fallow containers were arranged in a completely randomized experimental design on a greenhouse bench with average day and night temperatures of 24 and $19{ }^{\circ} \mathrm{C}$, respectively. Each container was irrigated (beaker-applied) with $500 \mathrm{~mL}$ tap water; the next day (designated Week 0) substrate solution was extracted using the pour-through method (Wright, 1986). Substrate solution $\mathrm{pH}$ and EC were measured using a Hanna HI 9811 instrument (Hanna Instruments, Woonsocket, RI), and extracts were frozen for later $\mathrm{NH}_{4}-\mathrm{N}$ and $\mathrm{NO}_{3}-\mathrm{N}$ analysis. Immediately after extracts were collected, each container was fertilized with $500 \mathrm{~mL}$ of a $200 \mathrm{mg} \cdot \mathrm{L}^{-1} \mathrm{~N}, 20 \mathrm{~N}-4.4 \mathrm{P}-16.6 \mathrm{~K}$, fertilizer solution with $\mathrm{N}$ from ammonium sulfate $\left[\left(\mathrm{NH}_{4}\right)_{2} \mathrm{SO}_{4}\right]$, phosphorus from phosphoric acid $\left(\mathrm{H}_{3} \mathrm{PO}_{4}\right)$, potassium from potassium chloride $(\mathrm{KCl})$ and micronutrients from Peters Special S.T.E.M (Peters Fertilizer Products, Allentown, PA; $\left.15 \mathrm{mg} \cdot \mathrm{L}^{-1}\right)$. The fertilizer solution $\mathrm{pH}$ was adjusted to $\approx 6.2$ using $2 \mathrm{~N}$ sodium hydroxide $(\mathrm{NaOH})$. At the end of Weeks 1 and 2, $250 \mathrm{~mL}$ of fertilizer solution was applied to each container; substrate solution was extracted $1 \mathrm{~h}$ after fertilizer addition at the end of Week 2 . At the end of Week 3, containers were irrigated with $250 \mathrm{~mL}$ of tap water to prevent EC values from exceeding $1.9 \mathrm{dS} \cdot \mathrm{m}^{-1}$. At the end of Week 4, containers were irrigated with $250 \mathrm{~mL}$ of fertilizer solution and $1 \mathrm{~h}$ later substrate solution was extracted. Extracts were analyzed for $\mathrm{NH}_{4}-\mathrm{N}$ using an $\mathrm{HNU}$ ionselective electrode (HNU Systems, Newton, $\mathrm{MA}$ ) and $\mathrm{NO}_{3}-\mathrm{N}$ using an Orion ion-selective electrode (Thermo Electron, Beverly, MA).

Containers with marigolds. Containers with marigolds were arranged in a completely randomized experimental design on a greenhouse bench adjacent to fallow pots. Each container was initially irrigated (beakerapplied) with $500 \mathrm{~mL}$ of a $300 \mathrm{mg} \cdot \mathrm{L}^{-1} \mathrm{~N}$ ( $8 \%$ ammonium, $12 \%$ nitrate), $20 \mathrm{~N}-4.4 \mathrm{P}$ 16.6K, complete fertilizer solution (Jack's Professional, Allentown, PA). The next day, $250 \mathrm{~mL}$ of fertilizer solution was applied. Until the time of harvest ( 3 weeks), all containers received $250 \mathrm{~mL}$ fertilizer solution when irrigation was needed with the exception that tap water was used to irrigate when substrate solution EC values exceeded $1.9 \mathrm{dS} \cdot \mathrm{m}^{-1}$. Irrigation frequency was based on conventional greenhouse irrigation practices. After 3 weeks, $250 \mathrm{~mL}$ fertilizer solution was added to each container, substrate solution was extracted $1 \mathrm{~h}$ later, and extract was analyzed for $\mathrm{pH}, \mathrm{EC}$, $\mathrm{NH}_{4}-\mathrm{N}$, and $\mathrm{NO}_{3}-\mathrm{N}$ as previously described. At Day 270 (Jan. 2010), plants were provided supplemental lighting using 400-W metal halide lamps from 0600 HR to 2000 HR daily.
Table 1. Monthly high, low, and average daily temperatures at the Urban Horticulture Center in Blacksburg, VA, where substrates were stored in plastic storage bags on shelves in an open shed.

\begin{tabular}{lccc}
\hline & High $\left({ }^{\circ} \mathrm{C}\right)$ & Low $\left({ }^{\circ} \mathrm{C}\right)$ & Avg daily $\left({ }^{\circ} \mathrm{C}\right)$ \\
\hline Apr. 2009 & 30 & -1 & 18 \\
May 2009 & 27 & 1 & 16 \\
June 2009 & 30 & 9 & 21 \\
July 2009 & 29 & 10 & 20 \\
Aug. 2009 & 30 & 14 & 21 \\
Sept. 2009 & 29 & 7 & 18 \\
Oct. 2009 & 29 & -3 & 11 \\
Nov. 2009 & 23 & -3 & 8 \\
Dec. 2009 & 15 & -12 & 1 \\
Jan. 2010 & 12 & -13 & -2 \\
Feb. 2010 & 7 & -8 & -2 \\
Mar. 2010 & 22 & -6 & 6 \\
Apr. 2010 & 29 & -1 & 14 \\
\hline
\end{tabular}

Data from fallow and planted containers were subjected to analysis of variance with mean separation by Tukey's honestly significant difference and regression analysis using JMP (Version 8; SAS Institute, Cary, NC).

Most probable number. Attempts were made to enumerate both ammonia-oxidizing microorganisms and nitrite-oxidizing microorganisms using a modified MPN technique (Alexander, 1982) as outlined by Schmidt and Belser (1994). The modification used deionized water instead of a phosphate buffer as a diluent because water has been shown to maximize oxidizer counts in substrates with low ammonium concentrations (Donaldson and Henderson, 1989). To estimate nitrifier population numbers present at subsampling Day $1,10 \mathrm{~cm}^{3}$ of air-dried substrate fine particles (less than $0.5 \mathrm{~mm}$ in diameter) from PTS without lime and PL without lime were each added to flasks containing $90 \mathrm{~mL}$ sterilized, deionized water and flasks were shaken vigorously by hand for $60 \mathrm{~s}\left(10^{-1}\right.$ dilution). Ten milliliters of this suspension were immediately and aseptically drawn from the flask and transferred to a second flask containing $90 \mathrm{~mL}$ sterilized, deionized water $\left(10^{-2}\right.$ dilution). This process was repeated until a $10^{-7} \mathrm{di}$ lution was established.

From each dilution, a 1-mL aliquot was added aseptically to each of five sterile polystyrene tubes containing $4 \mathrm{~mL}$ of ammoniaoxidizer medium and five sterile polystyrene tubes containing $4 \mathrm{~mL}$ nitrite-oxidizer medium. Tubes were incubated in the dark at $25 \pm 2{ }^{\circ} \mathrm{C}$ for 4 weeks and then checked for presence or absence of $\mathrm{NO}_{2}^{-}$as outlined by Schmidt and Belser (1994), indicating oxidation of $\mathrm{NH}_{4}{ }^{+}$in the ammonia oxidizer tubes and complete oxidation of $\mathrm{NO}_{2}{ }^{-}$to $\mathrm{NO}_{3}{ }^{-}$in the nitrite oxidizer tubes, respectively. Tubes were returned to the previous incubation setting and retested every 2 weeks until no change was detected for two successive testing periods. An estimate of the number of nitrite-oxidizing microorganisms was determined from the number of positive tubes per dilution and using the MPN table generated by Woomer (1994). Multiple attempts to enumerate ammonia-oxidizing microorganisms using varying media ammonium concentrations 
resulted in no to very low counts; these attempts were considered unsuccessful because nitrite oxidation was observed and depends on nitrite generation in the ammonia oxidation step. MPN assays were performed on non-limed PTS, PTS with $6 \mathrm{~kg} \cdot \mathrm{m}^{-3}$ lime, and PL with $6 \mathrm{~kg} \cdot \mathrm{m}^{-3}$ lime at all subsequent subsampling days. The $6-\mathrm{kg} \cdot \mathrm{m}^{-3}$ lime rate for PTS was chosen because substrate $\mathrm{pH}$ values would be the highest in this treatment over the experimental period, and $\mathrm{AOB}$ are reported to grow best in a near neutral environment (Prosser, 1989). There were three replications of each of the three substrates per subsampling day and mean oxidizer numbers and SEM were calculated using JMP (Version 8; SAS Institute, Inc.).

\section{Results and Discussion}

Fallow containers. Nitrate was detected in the substrate solution of PTS for each sampling day and the Week 0, 2, and 4 substrate solution extraction times with the exception of Day 42 when $\mathrm{NO}_{3}{ }^{-}$was absent at Week 2 (Table 2). Nitrate was also absent in non-limed PTS except at Week 4 of Day 270 and Week 4 of Day 365. For PTSP, $\mathrm{NO}_{3}{ }^{-}$was detected in the substrate solution for each sampling day and at the Week 0,2 , and 4 solution extraction times (Table 2). For Days 1,270 , and $365, \mathrm{NO}_{3}{ }^{-}$was present in the 2-, $4-$, and $6-\mathrm{kg} \cdot \mathrm{m}^{-3}$ lime rates in PTSP, whereas $\mathrm{NO}_{3}{ }^{-}$was only detected at the two highest lime rates for Days 42, 84, and 168. PTS and PTSP-filled containers were fertilized with $\mathrm{NH}_{4}{ }^{+}$as the sole $\mathrm{N}$ source; thus, the occurrence of nitrification was verified. There was a decrease in substrate solution $\mathrm{NH}_{4}-\mathrm{N}$ concentration with lime addition at all subsampling days for PTS and PTSP at Weeks 2 and 4 (no $\mathrm{NH}^{+}$was applied before Week 0) (Table 3). Addition of lime increased substrate solution $\mathrm{pH}$ in a quadratic fashion (Table 4), and the higher $\mathrm{pH}$ values of the limed treatments were more conducive to the activity and growth of nitrifying microorganisms, i.e., more $\mathrm{NH}_{4}{ }^{+}$was oxidized to $\mathrm{NO}_{3}{ }^{-}$. This is supported by work of Niemiera and Wright (1986a), who showed that $\mathrm{NO}_{3}{ }^{-}$production in a pine bark substrate increased with increasing lime rate. Increasing lime would have a slight effect, if any, on $\mathrm{NH}_{4}{ }^{+}$ adsorption to substrate particles in PTS because CEC for PTS is low $\left(-2.0 \mathrm{cmol} \cdot \mathrm{L}^{-1}\right.$; Jackson et al., 2008) and the fertilizer solution supplied a relatively high $\mathrm{NH}_{4}-\mathrm{N}$ concentration $\left(300 \mathrm{mg} \cdot \mathrm{L}^{-1}\right)$, enough to maintain exchange site saturation at all times. Additionally, calcium and magnesium from the lime, potassium, and other cations supplied by the fertilizer solution would have also adsorbed onto available exchange sites (substrate solution EC values were always between 1.5 and $2.4 \mathrm{ds} \cdot \mathrm{m}^{-1}$, data not shown). At Week 4 of subsampling Day 365, $\mathrm{NH}_{4}-\mathrm{N}$ concentration in the non-limed PTS ( $\mathrm{pH} 3.9)$ was the same as that for PTS at the $1-\mathrm{kg} \cdot \mathrm{m}^{-3}$ lime rate ( $\mathrm{pH}$ 5.7; Table 3 ). This also suggests that increased $\mathrm{NH}_{4}-\mathrm{N}$ adsorption to substrate particles with increasing lime rate is not the

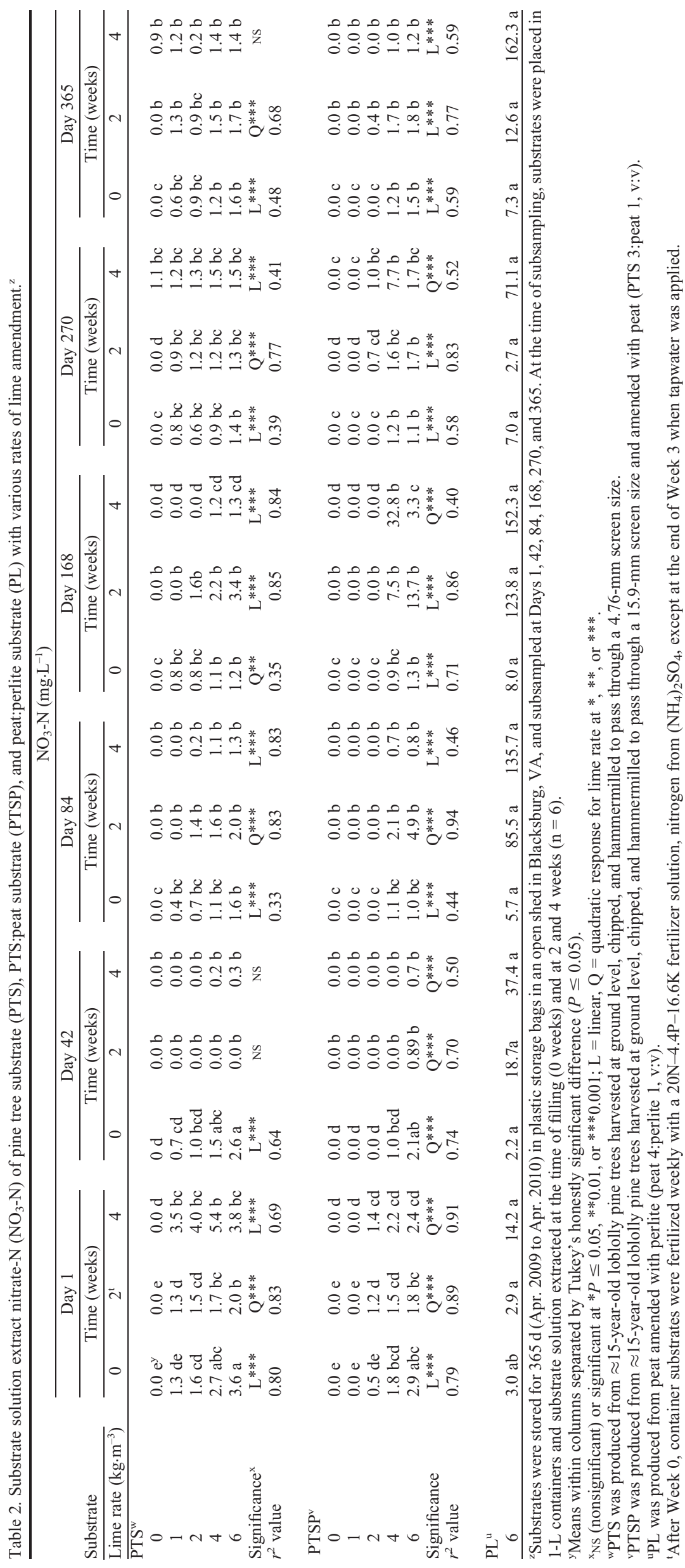




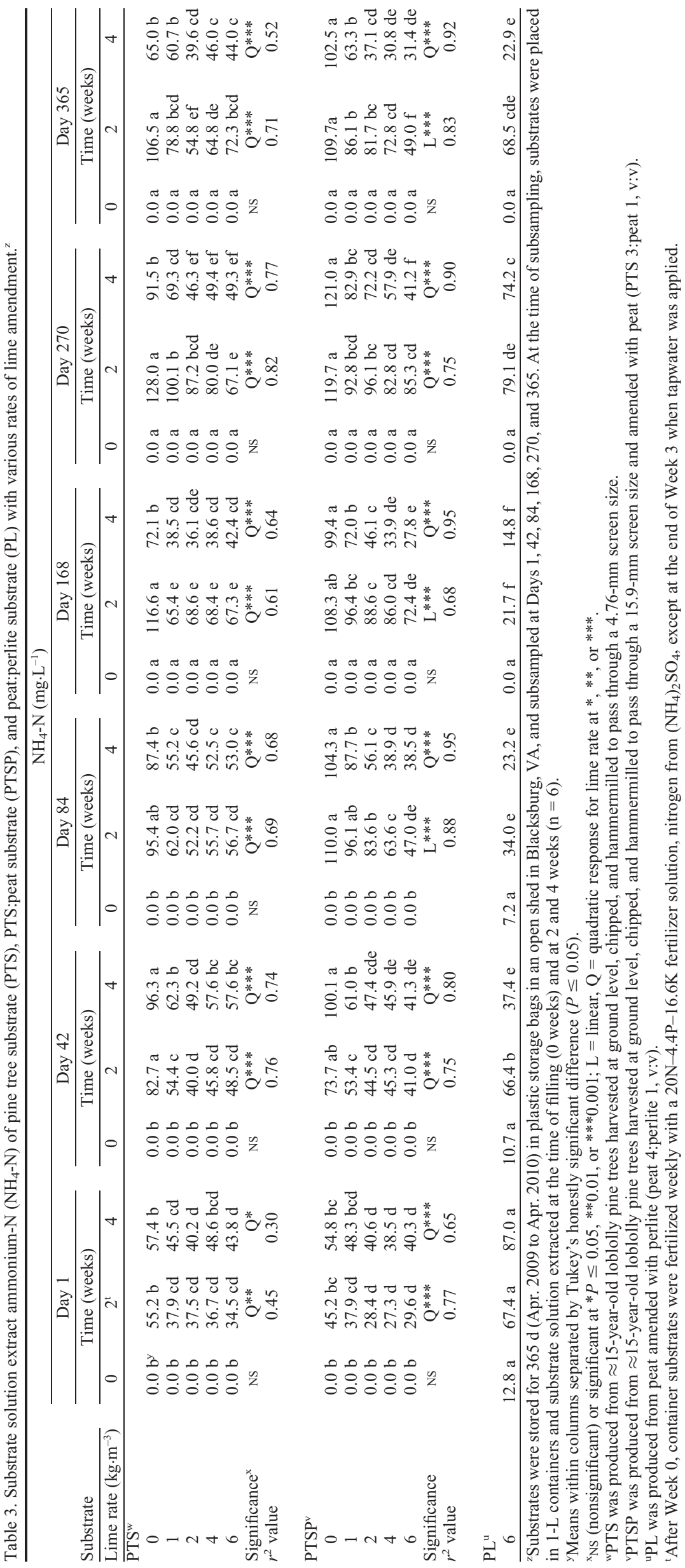

case or is not the major phenomenon responsible for lower $\mathrm{NH}_{4}^{+}$concentrations in limed substrates. Niemiera and Wright (1986a) demonstrated, with the use of a nitrification inhibitor, that $\mathrm{NH}_{4}-\mathrm{N}$ depletion in a pine bark substrate was mainly an effect of nitrification and not adsorption. Immobilization of $\mathrm{NH}_{4}{ }^{+}$ must also be considered. The higher $\mathrm{pH}$ values of all limed treatments were also more suitable for the growth and activity (Gray and Williams, 1971; Tate, 2000) of a more diverse bacterial community in general (Fierer and Jackson, 2006) than the lower $\mathrm{pH}$ values in the non-limed PTS. This would result in higher immobilization of ammonium in the limed PTS and PTSP treatments.

At subsampling Day $1, \mathrm{NO}_{3}-\mathrm{N}$ concentrations ranged from 0.5 to $3.6 \mathrm{mg} \cdot \mathrm{L}^{-1}$ in the Week 0 substrate solution extracts of all treatments except for non-limed PTS (pH 5.8), nonlimed PTSP ( $\mathrm{pH}$ 5.2), and the PTSP $1 \mathrm{~kg} \cdot \mathrm{m}^{-3}$ lime $(\mathrm{pH}$ 5.7) treatments (Table 2). Because this Week 0 measurement was taken before the addition of any fertilizer, the $\mathrm{NO}_{3}{ }^{-}$could have originated from one of three sources or any combination of the three. The $\mathrm{NO}_{3}{ }^{-}$could have 1) already been in the substrate at the time of manufacture; 2) been in the tap water used initially to saturate the substrate and then later used for the pour-through analysis (Blacksburg, VA, tap water contains less than $1 \mathrm{mg} \cdot \mathrm{L}^{-1} \mathrm{NO}_{3}-\mathrm{N}$ ); and/or 3 ) the product of nitrifying microorganisms that oxidized $\mathrm{NH}_{4}{ }^{+}$ that was indigenous to wood cells present at the time of PTS manufacture or released through mineralization during the initial 24-h incubation period. Because the PTS and PTSP treatments were prepared from the same wood source at the same time and because the tap water and amount used was the same for all treatments, the differences observed in $\mathrm{NO}_{3}{ }^{-}$ concentration would most likely be the result of different rates of nitrification, i.e., the higher the lime rate, the higher the $\mathrm{pH}$ value and the higher the rate of nitrification.

Nitrification, however, could not be ruled out in treatments with no measurable $\mathrm{NO}_{3}-\mathrm{N}$. The C:N ratios of the PTS and PTSP were $\approx 179: 1$ and 90:1 (Taylor et al., 2012), respectively, and the likelihood exists that some, if not most, of $\mathrm{NO}_{3}^{-}$produced was immobilized. For PTS, the highest (greater than $2 \mathrm{mg} \cdot \mathrm{L}^{-1}$ ) Day 1 Week $0 \mathrm{NO}_{3}$-N values occurred at the $4-$ and $6-\mathrm{kg} \cdot \mathrm{m}^{-3}$ lime rates (2.7 and $3.6 \mathrm{mg} \cdot \mathrm{L}^{-1}$, respectively); for PTSP, $\mathrm{NO}_{3}-\mathrm{N}$ concentration was $2.9 \mathrm{mg} \cdot \mathrm{L}^{-1}$ at the $6-\mathrm{kg} \cdot \mathrm{m}^{-3}$ lime rate (Table 4). The Week $0 \mathrm{NO}_{3}-\mathrm{N}$ concentration of $\mathrm{PL}$, a conventionally used substrate in which nitrification is known to occur, was $3.0 \mathrm{mg} \cdot \mathrm{L}^{-1}$ (pH 6.5). At all subsequent subsampling days, in almost all cases, $\mathrm{NO}_{3}-\mathrm{N}$ was detectable in PTS at a lower lime rate compared with PTSP. This emphasizes the acidifying effect of peat and its influence on nitrification. A relatively high $\mathrm{NO}_{3}-\mathrm{N}$ concentration $\left(32.8 \mathrm{mg} \cdot \mathrm{L}^{-1}\right)$ was detected in PTSP at Week 4 in the $4-\mathrm{kg} \cdot \mathrm{m}^{-3}$ lime rate (pH 6.0) at Day 168 (Table 4). The reason for this is not understood because such an increase was not observed in the $6-\mathrm{kg} \cdot \mathrm{m}^{-3}$ lime rate treatment with a higher $\mathrm{pH}(6.4)$ that 
Table 4. Substrate solution extract pH values of pine tree substrate (PTS), PTS:peat substrate (PTSP), and peat:perlite substrate (PL) with various rates of lime amendment. ${ }^{\mathrm{z}}$

\begin{tabular}{|c|c|c|c|c|c|c|c|c|c|c|c|c|c|c|c|c|c|c|}
\hline \multirow{4}{*}{$\frac{\text { Substrate }}{\text { Lime rate }\left(\mathrm{kg} \cdot \mathrm{m}^{-3}\right)}$} & \multicolumn{18}{|c|}{$\mathrm{pH}$} \\
\hline & \multicolumn{3}{|c|}{ Day 1} & \multicolumn{3}{|c|}{ Day 42} & \multicolumn{3}{|c|}{ Day 84} & \multicolumn{3}{|c|}{ Day 168} & \multicolumn{3}{|c|}{ Day 270} & \multicolumn{3}{|c|}{ Day 365} \\
\hline & \multicolumn{3}{|c|}{ Time (weeks) } & \multicolumn{3}{|c|}{ Time (weeks) } & \multicolumn{3}{|c|}{ Time (weeks) } & \multicolumn{3}{|c|}{ Time (weeks) } & \multicolumn{3}{|c|}{ Time (weeks) } & \multicolumn{3}{|c|}{ Time (weeks) } \\
\hline & 0 & $2^{t}$ & 4 & 0 & 2 & 4 & 0 & 2 & 4 & 0 & 2 & 4 & 0 & 2 & 4 & 0 & 2 & 4 \\
\hline \multicolumn{19}{|l|}{$\mathrm{PTS}^{\mathrm{w}}$} \\
\hline 0 & $5.8 \mathrm{e}^{\mathrm{y}}$ & $4.7 \mathrm{f}$ & $4.2 \mathrm{~g}$ & $5.2 \mathrm{~g}$ & $4.6 \mathrm{~h}$ & $4.4 \mathrm{~g}$ & $5.3 \mathrm{e}$ & $4.6 \mathrm{~g}$ & $4.5 \mathrm{~g}$ & $5.2 \mathrm{f}$ & $4.8 \mathrm{f}$ & $4.2 \mathrm{i}$ & $5.0 \mathrm{~g}$ & $4.5 \mathrm{~g}$ & $4.0 \mathrm{i}$ & $5.0 \mathrm{~g}$ & $4.4 \mathrm{~h}$ & $3.9 \mathrm{j}$ \\
\hline 1 & $6.2 \mathrm{~cd}$ & $6.1 \mathrm{~d}$ & $6.7 \mathrm{~b}$ & $5.8 \mathrm{e}$ & $5.7 \mathrm{f}$ & $5.9 \mathrm{~d}$ & $6.3 \mathrm{c}$ & $6.0 \mathrm{~d}$ & $6.1 \mathrm{c}$ & $6.4 \mathrm{~d}$ & $5.8 \mathrm{~d}$ & $5.7 \mathrm{e}$ & $6.2 \mathrm{e}$ & $5.8 \mathrm{e}$ & $5.6 \mathrm{f}$ & $6.3 \mathrm{~d}$ & $5.7 \mathrm{e}$ & $5.7 \mathrm{e}$ \\
\hline 2 & $6.3 \mathrm{bc}$ & $6.4 \mathrm{c}$ & $6.9 \mathrm{a}$ & $6.0 \mathrm{~d}$ & $6.0 \mathrm{e}$ & $6.2 \mathrm{c}$ & $6.7 \mathrm{~b}$ & $6.4 \mathrm{c}$ & $6.4 \mathrm{~b}$ & $6.6 \mathrm{c}$ & $6.1 \mathrm{c}$ & $6.1 \mathrm{c}$ & $6.6 \mathrm{c}$ & $5.9 \mathrm{~d}$ & $6.0 \mathrm{~d}$ & $6.5 \mathrm{~b}$ & $5.8 \mathrm{~d}$ & $6.0 \mathrm{~d}$ \\
\hline 4 & $6.5 \mathrm{ab}$ & $6.6 \mathrm{~b}$ & $6.9 \mathrm{a}$ & $6.3 \mathrm{~b}$ & $6.4 \mathrm{c}$ & $6.4 \mathrm{~b}$ & $6.8 \mathrm{~b}$ & $6.6 \mathrm{~b}$ & $6.6 \mathrm{a}$ & $6.8 \mathrm{a}$ & $6.3 \mathrm{~b}$ & $6.3 \mathrm{~b}$ & $6.8 \mathrm{~b}$ & $6.2 \mathrm{c}$ & $6.2 \mathrm{c}$ & $6.7 \mathrm{a}$ & $6.0 \mathrm{c}$ & $6.3 \mathrm{~b}$ \\
\hline 6 & $6.6 \mathrm{a}$ & $6.7 \mathrm{a}$ & $6.9 \mathrm{a}$ & $6.5 \mathrm{a}$ & $6.6 \mathrm{a}$ & $6.5 \mathrm{a}$ & $7.0 \mathrm{a}$ & $6.7 \mathrm{a}$ & $6.7 \mathrm{a}$ & $6.9 \mathrm{a}$ & $6.4 \mathrm{~b}$ & $6.4 \mathrm{a}$ & $6.9 \mathrm{a}$ & $6.3 \mathrm{~b}$ & $6.3 \mathrm{~b}$ & $6.8 \mathrm{a}$ & $6.4 \mathrm{a}$ & $6.4 \mathrm{a}$ \\
\hline Significance $^{\mathrm{x}}$ & $\mathrm{Q}^{* * *}$ & $\mathrm{Q}^{* * *}$ & $\mathrm{Q}^{* * *}$ & $\mathrm{Q}^{* * *}$ & $\mathrm{Q}^{* * *}$ & $\mathrm{Q}^{* * *}$ & $\mathrm{Q}^{* * *}$ & $\mathrm{Q}^{* * *}$ & $\mathrm{Q}^{* * *}$ & $\mathrm{Q}^{* * *}$ & $\mathrm{Q}^{* * *}$ & $\mathrm{Q}^{* * *}$ & $\mathrm{Q}^{* * *}$ & $\mathrm{Q}^{* * *}$ & $\mathrm{Q}^{* * *}$ & $\mathrm{Q}^{* * *}$ & $\mathrm{Q} * * *$ & $\mathrm{Q}^{* * *}$ \\
\hline$r^{2}$ & 0.84 & 0.86 & 0.78 & 0.94 & 0.94 & 0.89 & 0.89 & 0.89 & 0.87 & 0.88 & 0.92 & 0.89 & 0.91 & 0.87 & 0.89 & 0.9 & 0.85 & 0.89 \\
\hline \multicolumn{19}{|l|}{ PTSP $^{v}$} \\
\hline 0 & $5.2 \mathrm{f}$ & $4.6 \mathrm{f}$ & $4.0 \mathrm{~h}$ & $4.3 \mathrm{i}$ & $4.2 \mathrm{i}$ & $4.0 \mathrm{~h}$ & $4.4 \mathrm{~g}$ & $4.2 \mathrm{~h}$ & $4.2 \mathrm{~h}$ & $4.4 \mathrm{~h}$ & $4.2 \mathrm{~g}$ & $3.9 \mathrm{j}$ & $4.0 \mathrm{i}$ & $3.7 \mathrm{~h}$ & $3.7 \mathrm{~h}$ & $4.1 \mathrm{i}$ & $3.9 \mathrm{i}$ & $4.0 \mathrm{i}$ \\
\hline 1 & $5.7 \mathrm{e}$ & $5.2 \mathrm{e}$ & $5.0 \mathrm{f}$ & $5.0 \mathrm{~h}$ & $5.0 \mathrm{~g}$ & $4.7 \mathrm{f}$ & $5.1 \mathrm{f}$ & $5.0 \mathrm{f}$ & $4.9 \mathrm{f}$ & $5.1 \mathrm{~g}$ & $4.9 \mathrm{f}$ & $4.6 \mathrm{~h}$ & $4.8 \mathrm{~h}$ & $4.5 \mathrm{~g}$ & $4.4 \mathrm{~h}$ & $4.7 \mathrm{~h}$ & $4.5 \mathrm{~g}$ & $4.5 \mathrm{~h}$ \\
\hline 2 & $6.1 \mathrm{~d}$ & $6.0 \mathrm{~d}$ & $5.9 \mathrm{e}$ & $5.4 \mathrm{f}$ & $5.7 \mathrm{f}$ & $5.4 \mathrm{e}$ & $5.7 \mathrm{~d}$ & $5.8 \mathrm{e}$ & $5.5 \mathrm{e}$ & $5.7 \mathrm{e}$ & $5.6 \mathrm{e}$ & $5.3 \mathrm{~g}$ & $5.5 \mathrm{f}$ & $5.4 \mathrm{f}$ & $5.3 \mathrm{~g}$ & $5.4 \mathrm{f}$ & $5.3 \mathrm{f}$ & $5.2 \mathrm{~g}$ \\
\hline 4 & $6.4 \mathrm{ab}$ & $6.5 \mathrm{bc}$ & $6.4 \mathrm{~cd}$ & $6.1 \mathrm{c}$ & $6.2 \mathrm{~d}$ & $6.1 \mathrm{c}$ & $6.4 \mathrm{c}$ & $6.4 \mathrm{c}$ & $6.3 \mathrm{~b}$ & $6.4 \mathrm{~d}$ & $6.4 \mathrm{~b}$ & $6.0 \mathrm{~d}$ & $6.2 \mathrm{e}$ & $6.4 \mathrm{~b}$ & $6.1 \mathrm{~d}$ & $6.1 \mathrm{e}$ & $6.1 \mathrm{~b}$ & $6.1 \mathrm{c}$ \\
\hline 6 & $6.6 \mathrm{a}$ & $6.7 \mathrm{a}$ & $6.5 \mathrm{c}$ & $6.4 \mathrm{a}$ & $6.5 \mathrm{~b}$ & $6.3 \mathrm{~b}$ & $6.8 \mathrm{~b}$ & $6.6 \mathrm{ab}$ & $6.6 \mathrm{a}$ & $6.7 \mathrm{~b}$ & $6.5 \mathrm{a}$ & $6.4 \mathrm{a}$ & $6.6 \mathrm{c}$ & $6.6 \mathrm{a}$ & $6.4 \mathrm{a}$ & $6.4 \mathrm{c}$ & $6.4 \mathrm{a}$ & $6.4 \mathrm{a}$ \\
\hline Significance & $\mathrm{Q}^{* * *}$ & $\mathrm{Q}^{* * *}$ & $\mathrm{Q}^{* * *}$ & $\mathrm{Q}^{* * *}$ & $\mathrm{Q}^{* * *}$ & $\mathrm{Q}^{* * *}$ & $\mathrm{Q}^{* * *}$ & $\mathrm{Q}^{* * *}$ & $\mathrm{Q}^{* * *}$ & $\mathrm{Q}^{* * *}$ & $\mathrm{Q}^{* * *}$ & $\mathrm{Q}^{* * *}$ & $\mathrm{Q}^{* * *}$ & $\mathrm{Q}^{* * *}$ & $\mathrm{Q}^{* * *}$ & $\mathrm{Q}^{* * *}$ & $\mathrm{Q}^{* * *}$ & $\mathrm{Q}^{* * *}$ \\
\hline$r^{2}$ & 0.98 & 0.99 & 0.99 & 1.00 & 0.99 & 1.00 & 0.99 & 0.99 & 1.00 & 1.00 & 1.00 & 0.99 & 0.99 & 0.99 & 0.99 & 0.99 & 0.99 & 0.99 \\
\hline
\end{tabular}

$\mathrm{PL}^{\mathrm{u}}$

6

\begin{tabular}{lllllllllllllllllll}
$6.5 \mathrm{a}$ & $6.5 \mathrm{bc}$ & $6.3 \mathrm{~d}$ & $6.2 \mathrm{bc}$ & $6.3 \mathrm{~d}$ & $5.8 \mathrm{~d}$ & $6.5 \mathrm{c}$ & $5.9 \mathrm{~d}$ & $5.8 \mathrm{~d}$ & $6.4 \mathrm{~d}$ & $5.8 \mathrm{~d}$ & $5.6 \mathrm{f}$ & $6.5 \mathrm{~d}$ & $6.2 \mathrm{c}$ & $5.7 \mathrm{e}$ & $6.4 \mathrm{c}$ & $6.1 \mathrm{~b}$ & $5.6 \mathrm{f}$ \\
\hline
\end{tabular}

${ }^{z}$ Substrates were stored for 365 d (Apr. 2009 to Apr. 2010) in plastic storage bags in an open shed in Blacksburg, VA, and subsampled at Days 1, 42, 84, 168, 270, and 365 . At the time of subsampling, substrates were placed in 1-L containers and substrate solution extracted at the time of filling ( 0 weeks) and at 2 and 4 weeks $(\mathrm{n}=6)$.

${ }^{\mathrm{y}}$ Means within columns separated by Tukey's honestly significant difference $(P \leq 0.05)$. $\mathrm{n}=6$.

${ }^{\mathrm{x}} \mathrm{NS}$ (nonsignificant) or significant at $* P \leq 0.05, * * 0.01$, or $* * * 0.001 ; \mathrm{L}=$ linear, $\mathrm{Q}=$ quadratic response for lime rate at $*, * *$, or $* * *$.

wPTS was produced from $\approx 15$-year-old loblolly pine trees harvested at ground level, delimbed, chipped, and hammermilled to pass through a 4.76-mm screen.

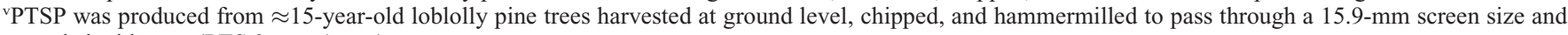
amended with peat (PTS 3:peat 1, v:v).

uPL is produced from peat amended with perlite (peat 4:perlite 1, v:v).

${ }^{\mathrm{t}}$ After Week 0 , container substrates were fertilized weekly with a $20 \mathrm{~N}-4.4 \mathrm{P}-16.6 \mathrm{~K}$ fertilizer solution, nitrogen from $\left(\mathrm{NH}_{4}\right)_{2} \mathrm{SO} \mathrm{H}_{4}$, except at the end of Week 3 when tapwater was applied.

would have presumably been more conducive to nitrification. By Day 270, $\mathrm{NO}_{3}-\mathrm{N}$ values were significantly less and more similar to Day 84 subsampling day values.

Most probable number. At subsampling Day 1 , the number of nitrite oxidizers in nonlimed PTS (pH 5.8) was approximately half that of PL (Table 5). Although attempts to enumerate ammonia-oxidizing microorganisms were unsuccessful, their presence is strongly supported, because the existence of viable populations of nitrite-oxidizing microorganisms implies viable populations of ammonia oxidizers. When $\mathrm{NO}_{2}^{-}$is found in soils, $\mathrm{NH}_{4}^{+}$oxidation is the presumed precursor reaction (Tate, 2000). By Day 42, the number of nitrite oxidizers estimated in both non-limed PTS and PTS with $6 \mathrm{~kg} \cdot \mathrm{m}^{-3}$ lime (23 organisms per $\mathrm{mL}$ of substrate for both) was considerably less than Day 1 PTS. An influence other than $\mathrm{pH}$ was responsible for the decline in numbers, at least in the limed treatment, because the $\mathrm{pH}$ of this limed PTS was 6.5. Competition for available $\mathrm{N}$ with other more robust microbes is a likely possibility. Furthermore, because these surviving nitrite oxidizers are poor competitors (Prosser, 1989), the lack of $\mathrm{NO}_{3}-\mathrm{N}$ at Week 2 of Day 42 (Table 2), regardless of lime rate, in PTS is understandable as is the lack of measurable $\mathrm{NO}_{3}-\mathrm{N}$ in any but the highest lime rate of PTSP because there was a sharp decrease in the number of nitrite oxidizers in PL by Day 42. The C:N of PL (53:1; Taylor et al.,

Table 5. Most probable number (MPN) estimates of nitrite-oxidizing microorganisms present in non-limed and limed pine tree substrate (PTS) and peat-perlite substrate (PL) after 1, 42, 84, 168, 270, and $365 \mathrm{~d}$ of storage in plastic bags in an open shed in Blacksburg, VA.

\begin{tabular}{|c|c|c|c|c|c|c|}
\hline \multirow[b]{2}{*}{ Substrate } & \multicolumn{6}{|c|}{ MPN (organisms $/ \mathrm{cm}^{3}$ ) } \\
\hline & \multicolumn{6}{|c|}{ Day } \\
\hline$\overline{\text { Lime rate }\left(\mathrm{kg} \cdot \mathrm{m}^{-3}\right)}$ & 1 & 42 & 84 & 168 & 270 & 365 \\
\hline$\overline{\mathrm{PTS},{ }^{\mathrm{y}} 0}$ & $119(56)^{z}$ & $23(0)$ & $23(0)$ & $23(0)$ & $26(3)$ & $23(0)$ \\
\hline PTS, 6 & ${ }^{\mathrm{w}}$ & $23(0)$ & $23(0)$ & $23(0)$ & $23(0)$ & $23(0)$ \\
\hline $\mathrm{PL},{ }^{\mathrm{x}} 6$ & $230(0)$ & $8(2)$ & $348(75)$ & $1719(515)$ & $3454(802)$ & $7755(2897)$ \\
\hline
\end{tabular}

${ }^{\mathrm{z}} \mathrm{SEM}, \mathrm{n}=3$.

yPTS is produced from $\approx 15$-year-old loblolly pine trees harvested at ground level, chipped, and hammermilled to pass through a 4.76-mm screen size.

${ }^{x} \mathrm{PL}$ is produced from peat amended with perlite (peat 4:perlite 1, v:v).

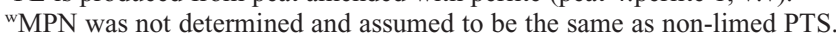

2012) is much lower that the approximate 179:1 value of PTS (Taylor et al., 2012) and this may explain why, although nitrite oxidizer numbers are low at Day 42 in $\mathrm{PL}, \mathrm{NO}_{3}-\mathrm{N}$ concentration increased from Week 0 to Weeks 2 and 4. A lower C:N ratio implies a lesser amount of immobilization in PL than in PTS and PTSP and therefore more $\mathrm{NO}_{3}-\mathrm{N}$ would be present in a PL substrate solution than a PTS substrate solution. Nitrite oxidizer numbers remained steady at $\approx 23$ organisms per $\mathrm{cm}^{3}$ of substrate at all remaining subsampling days for PTS and PTS with $6 \mathrm{~kg} \cdot \mathrm{m}^{-3}$ lime, as did $\mathrm{NO}_{3}-\mathrm{N}$ values in the fallow containers. Nitrite oxidizers, and presumably ammonia oxidizers, were able to survive in storage over $365 \mathrm{~d}$. Interestingly, PL nitrite oxidizer numbers increased substantially from
Day 42 through Day 365 and by Day 365 , there was an estimated 7755 organisms per $\mathrm{cm}^{3}$ of substrate. $\mathrm{PL} \mathrm{NO}_{3}-\mathrm{N}$ values likewise increased and were measured at over $100 \mathrm{mg} \cdot \mathrm{L}^{-1}$, except at subsampling Day 270 when $\mathrm{NO}_{3}-\mathrm{N}$ was $71.1 \mathrm{mg} \cdot \mathrm{L}^{-1}$.

Marigold substrate solution extract studies. Variation in substrate $\mathrm{pH}$ values within lime rate was greater in the marigold studies than in the fallow pot studies (especially in the weakly buffered PTS; data not shown), most likely as a result of plant-soil interactions. Results of $\mathrm{NH}_{4}-\mathrm{N}$ and $\mathrm{NO}_{3}-\mathrm{N}$ values $\left(\mathrm{NH}_{4}: \mathrm{NO}_{3}\right.$ ratios) will therefore be presented on a $\mathrm{pH}$ rather than a lime rate basis. As substrate $\mathrm{pH}$ increased, $\mathrm{NH}_{4}: \mathrm{NO}_{3}$ ratios decreased in the substrate solution extracts taken at harvest (Week 3; 21-d growing period) at all subsampling days 
and in both PTS and PTSP (Fig. 1). For all but one subsampling day in PTS (Day 270) and $1 \mathrm{~d}$ in PTSP (Day 1), the $r^{2}$ value describing the decreasing $\mathrm{NH}_{4}: \mathrm{NO}_{3}$ ratios with increasing $\mathrm{pH}$ was 0.57 or greater and 0.81 or greater, respectively. These trends in $\mathrm{NH} 4-\mathrm{N}: \mathrm{NO}_{3}-\mathrm{N}$ ratios support the occurrence of nitrification in PTS and PTSP because nitrification generally increases as substrate $\mathrm{pH}$ increases in the 5.0 to $7.0 \mathrm{pH}$ range. This relationship could have been a result of 1) preferential immobilization of $\mathrm{NH}_{4}^{+}$over $\mathrm{NO}_{3}^{-}$as $\mathrm{pH}$ increased; 2) preferential root uptake of $\mathrm{NH}_{4}{ }^{+}$over $\mathrm{NO}_{3}{ }^{-}$as $\mathrm{pH}$ increased; 3 ) increased adsorption of $\mathrm{NH}_{4}{ }^{+}$ to substrate particles as $\mathrm{pH}$ increased; and 4) increase in nitrification rate as $\mathrm{pH}$ increased. The preference by microorganisms as well as by plants for $\mathrm{NH}_{4}^{+}$over $\mathrm{NO}_{3}^{-}$occurs when microbial metabolic energy is limited because energy is necessary to reduce $\mathrm{NO}_{3}{ }^{-}$to $\mathrm{NH}_{4}{ }^{+}$for subsequent incorporation into amino acids (Sylvia et al., 2005). However, in this study, metabolic energy was not limiting for either the microorganisms or plants because both groups were supplied with essential nutrients, water, and energy in the form of carbonhydrogen bonds (substrate- or plant-derived) for microorganisms and sunlight (auxiliary lighting supplied on Day 270) for plants. Furthermore, a study by El Jaoual and Cox
(1998) showed that $\mathrm{NO}_{3}{ }^{-}$(and not $\mathrm{NH}_{4}{ }^{+}$) was preferentially absorbed for the first $50 \mathrm{~d}$ of marigold growth (Tagetes erecta L. 'First Lady'). As mentioned earlier, increased adsorption of $\mathrm{NH}_{4}^{+}$to substrate particles is expected to be negligible as lime rate increases in a PTS- and PTS-based substrate. An increase in nitrification, therefore, seems to be the most plausible explanation. The relatively low $\mathrm{NH}_{4}-\mathrm{N}: \mathrm{NO}_{3}-\mathrm{N}$ ratios at Days 270 and 365 at all lime rates in PTS suggested the occurrence of nitrification at low $\mathrm{pH}$ values as well as the higher values. In support of this, there was measurable $\mathrm{NO}_{3}-\mathrm{N}$ in the non-limed PTS in the fallow container study at 4 weeks at both

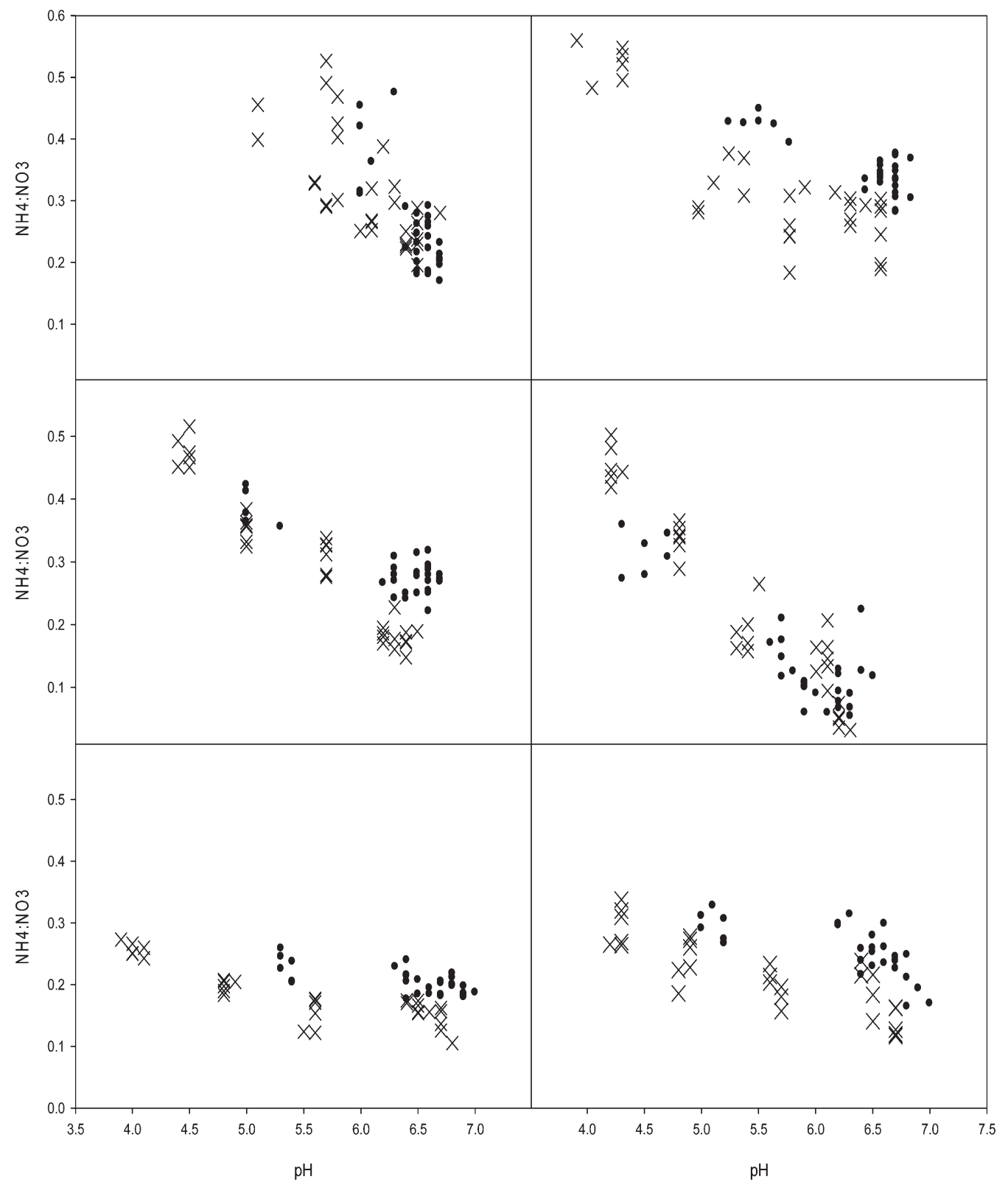

Fig. 1. Marigold substrate solution extract $\mathrm{NH}_{4}: \mathrm{NO}_{3}$ ratio after 3 weeks of fertilization with a complete 20-10-20 fertilizer solution at 6 subsampling days from Apr. 2009 to Apr. 2010 for pine tree substrate $(\bullet, P T S)$ and pine tree:peat $(3: 1, \mathrm{v}: \mathrm{v})$ substrate $(\mathrm{X}, \mathrm{PTSP})$. (A) Day $1\left(\mathrm{PTS}: \mathrm{y}=1.9580-0.2624 \mathrm{x}, r^{2}=0.57, P<\right.$ 0.0001 and PTSP: $\left.\mathrm{y}=1.1869-0.1439 \mathrm{x}, r^{2}=0.46, P<0.0001\right)$; (B) Day $42\left[\right.$ PTS: $\mathrm{y}=1.0340-0.1025 \mathrm{x}, r^{2}=0.69, P<0.0001$ and PTSP: $\mathrm{y}=0.9151-0.1040 \mathrm{x}+$ $\left.0.1014(\mathrm{x}-6.0767)^{2}, r^{2}=0.81, P<0.0001\right]$; (C) Day 84 [PTS: $\mathrm{y}=0.4422-0.0269 \mathrm{x}+0.0555(\mathrm{x}-6.21)^{2}, r^{2}=0.78, P<0.0001$ and PTSP: $\mathrm{y}=1.1269-0.1487 \mathrm{x}$, $\left.r^{2}=0.93, P<0.0001\right]$; (D) Day 168 [PTS: $\mathrm{y}=0.6466-0.0902 \mathrm{x}+0.0448(\mathrm{x}-5.7333)^{2}, r^{2}=0.78, P<0.0001$ and PTSP: $\mathrm{y}=1.2344-0.1870 \mathrm{x}, r^{2}=0.91, P<$ 0.0001 ]; (E) Day 270 [PTS: $\mathrm{y}=0.3637-0.0248 \mathrm{x}, r^{2}=0.43, P<0.0001$ and for PTSP: $\left.\mathrm{y}=0.3482-0.0334 \mathrm{x}=0.0187(\mathrm{x}-5.5167)^{2}, r^{2}=0.83, P<0.0001\right] ;(\mathbf{F})$ Day 365 [PTS: $\mathrm{y}=0.8548-0.0909 \mathrm{x}-0.0653(\mathrm{x}-6.2679)^{2}, r^{2}=0.63, P<0.0001$ and for PTSP: $\left.\mathrm{y}=0.5285-0.0559 \mathrm{x}, r^{2}=0.69, P<0.0001\right]$. 
sampling Days 270 and 365 (Table 2), whereas none had been detected in previous subsampling days.

The acidifying effect of nitrification would be expected to cause $\mathrm{pH}$ values to decrease over the 3-week growing period. For subsampling Days 0 and 42, $\mathrm{pH}$ values remained the same or increased for all PTS and PTSP lime treatments (Table 6). A pH increase of nonlimed PTS in plant production after the addition of an acid-forming fertilizer has been noted previously (Gruda et al., 2009) and the reason for this is unclear. The possibility exists that the preferential uptake of $\mathrm{NO}_{3}{ }^{-}$by marigolds resulted in an increase in rhizosphere $\mathrm{pH}$ and, therefore, substrate $\mathrm{pH}$ by symport of hydrogen with $\mathrm{NO}_{3}{ }^{-}$absorption. In the limed treatments, this increase can be explained by the action of lime. A pH decrease did not occur until subsampling Day 84 (in July; Table 6) when warmer temperatures prevailed. Greater $\mathrm{pH}$ decreases occurred at subsampling Day 168 (October) compared with July. By subsampling Days 270 (January) and 365 (April), $\mathrm{pH}$ values began increasing again after 3 weeks of marigold growth (Table 6).

Results of this study support the occurrence of nitrification in PTS and PTSP. MPN assays demonstrated that nitrite-oxidizing microorganisms were present throughout the $365 \mathrm{~d}$ of the experiment in PTS. Nitrate was measurable in $\mathrm{NH}_{4}{ }^{+}$-fertilized fallow pots with a positive correlation between substrate solution $\mathrm{pH}$ and $\mathrm{NO}_{3}-\mathrm{N}$. Ammonium-N to $\mathrm{NO}_{3}-\mathrm{N}$ ratios decreased with increasing $\mathrm{pH}$ as a result of liming rate, which was expected if nitrification rate was greater at the higher $\mathrm{pH}$ values than at lower $\mathrm{pH}$ values. However, in PTS, there was evidence that nitrification proceeded in low $\mathrm{pH}$ situations, especially after storage for $270 \mathrm{~d}$. Whether the nitrifying microorganisms involved had adapted in some way to acid conditions or whether different nitrifying species had become established is unclear.

Although nitrification is supported in PTS and PTSP, the contribution it makes to plant available nitrate appears to be small, at least for the first 3 to 4 weeks of plant production, which, for some crop species, would be the entire production cycle. Nitrifying microorganisms are poor competitors and when $\mathrm{C}: \mathrm{N}$ ratios are as high as in PTS and PTSP, they are no match for heterotrophic microorganisms; $\mathrm{NO}_{3}{ }^{-}$production, then, is low and any $\mathrm{NO}_{3}{ }^{-}$produced is immobilized. Nitrate-N would need to be incorporated in the fertilizer to supply nitrate and protect against $\mathrm{NH}_{4}$ toxicity. Other solutions may be to lower the $\mathrm{C}: \mathrm{N}$ ratio by composting, or preplant incorporation of $\mathrm{N}$, as demonstrated by Gruda and Schnitzler (1999) with shredded spruce wood chippings. There is evidence (L. Taylor, unpublished data) that nitrifiers build up populations over relatively long periods of time in PTS container-grown plant production (e.g., more than six to 12 months as is the case in some large nursery stock); hence, nitrification may supply enough nitrate to render the $\mathrm{NH}_{4}: \mathrm{NO}_{3}$ ratio suitable for most plant species.

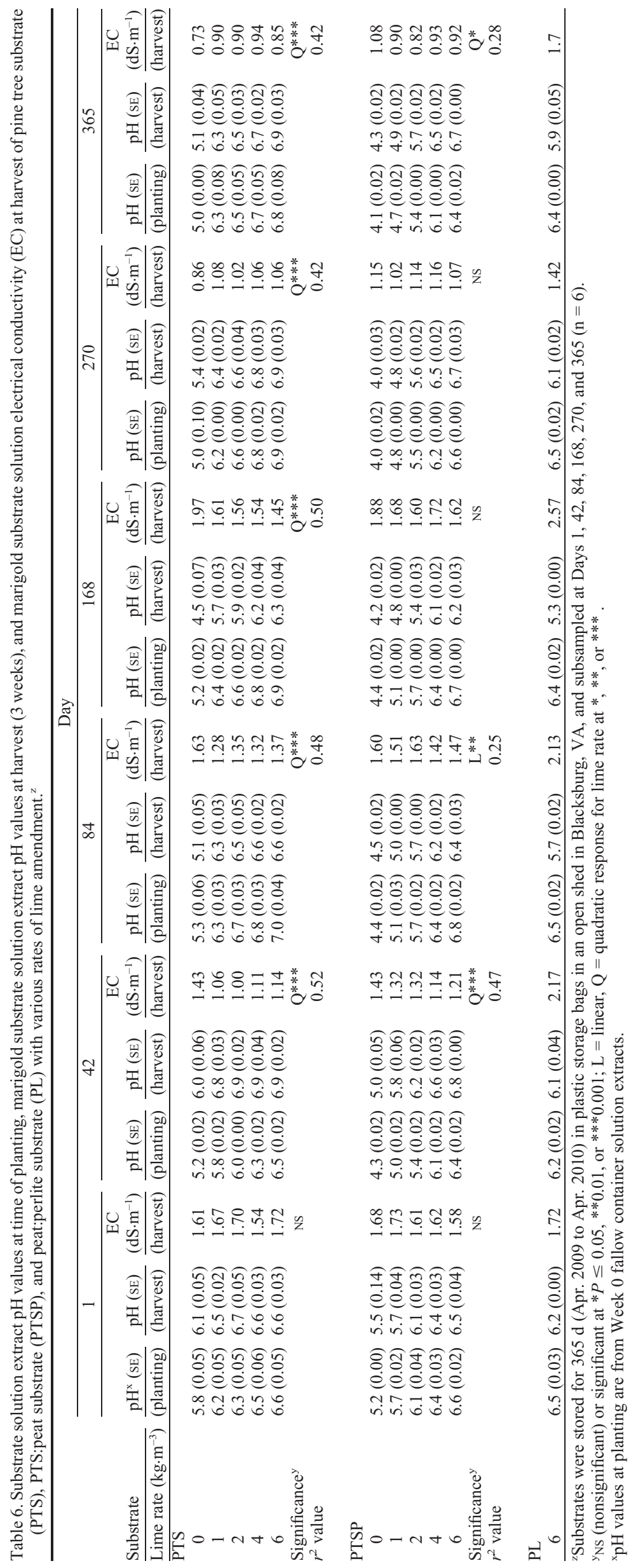

HortScience Vol. 48(1) JanUary 2013 


\section{Literature Cited}

Alexander, M. 1982. Most probable number method for microbial populations. p. 815-820. In: Page, A.L. (ed.). Methods of soil analysis. Part 2. 2nd Ed. American Society of Agronomy and Soil Science Society of America, Madison, WI.

Barker, A.V. and H.A. Mills. 1980. Ammonium and nitrate nutrition of horticultural crops. Hort. Rev. 2:394-423.

Brierley, E.D.R. and M. Wood. 2001. Heterotrophic nitrification in an acid forest soil: Isolation and characterisation of a nitrifying bacterium. Soil Biol. Biochem. 33:1403-1409.

Donaldson, J. and G.S. Henderson. 1989. A dilute medium to determine population size of ammonium oxidizers in forest soils. Soil Sci. Soc. Amer. J. 53:1608-1611.

El-Jaoual, T. and D. Cox. 1998. Effects of plant age on nitrogen uptake and distribution by greenhouse plants. J. Plant Nutr. 21:1055-1066.

Elliott, G. 1986. Urea hydrolysis in potting media. J. Amer. Soc. Hort. Sci. 111:862-866.

Fierer, N. and R.B. Jackson. 2006. The diversity and biogeography of soil bacterial communities. Proc. Natl. Acad. Sci. USA 103:626-631.

Gray, T.R.G. and S.T. Williams. 1971. Soil microorganisms. p. 30-50. In: Heywood, V.H. (ed.). University reviews in botany. Oliver and Boyd, Edinburgh, UK.

Gruda, N., B.J. Rau, and R.D. Wright. 2009. Laboratory bioassay and greenhouse evaluation of a pine tree substrate used as a container substrate. Eur. J. Hort. Sci. 74:73-78.

Gruda, N. and W.H. Schnitzler. 1999. Influence of wood fiber substrates and nitrogen application rates on the growth of tomato transplants. Adv. Hort. Sci. 13:20-24.

Jackson, B.E., R.D. Wright, and M.C. Barnes. 2010. Methods of constructing a pine tree substrate from various wood particle sizes, organic amendments, and sand for desired physical properties and plant growth. HortScience 45:103-112.

Jackson, B.E., R.D. Wright, J.F. Browder, J.R. Harris, and A.X. Niemiera. 2008. Effect of fertilizer rate on growth of azalea and holly in pine bark and pine tree substrates. HortScience 43:1561-1568.

Jackson, B.E., R.D. Wright, and N. Gruda. 2009. Container medium $\mathrm{pH}$ in a pine tree substrate amended with peatmoss and dolomitic limestone affects plant growth. HortScience 44: 1983-1987.

Lang, E. and G. Jagnow. 1986. Fungi of a forest soil nitrifying at low $\mathrm{pH}$ values. FEMS Microbiol. Ecol. 38:257-265.

Lang, H. and G.C. Elliott. 1991. Influence of ammonium: Nitrate ratio and nitrogen concentration on nitrification activity in soilless potting media. J. Amer. Soc. Hort. Sci. 116:642645.

Nelson, P.V. 2003. Greenhouse operation and management. 6th Ed. Prentice Hall, Englewood Cliffs, NJ.

Niemiera, A. and R.D. Wright. 1986a. Effect of liming rate on nitrification in a pine bark medium. J. Amer. Soc. Hort. Sci. 111:713-715.

Niemiera, A. and R.D. Wright. 1986b. The influence of nitrification on the medium solution and growth of holly, azalea, and juniper in a pine bark medium. J. Amer. Soc. Hort. Sci. 111: 708-712.

Niemiera, A. and R.D. Wright. 1987a. Influence of $\mathrm{NH}_{4}-\mathrm{N}$ application rate on nitrification in a pine bark medium. HortScience 22:616-618.

Niemiera, A. and R.D. Wright. 1987b. Influence of temperature on nitrification in a pine bark medium. HortScience 22:615-616.

Prosser, J.I. 1989. Autotrophic nitrification in bacteria. Adv. Microb. Physiol. 30:125-181.

Saunders, T., R. Wright, and J.F. Browder. 2005. Chipped pine logs: A potential substrate for nursery and greenhouse crops. Proc. Southern Nursery Assn. Res. Conf. 50:112-114.

Schmidt, E.L. and L.W. Belser. 1994. Autotrophic nitrifying bacteria, p. 159-177. In: Weaver, R.W. (ed.). Methods of soil analysis. Part 2. Microbiological and biochemical properties. Soil Science Society of America, Madison, WI.
Stowe, D.C., M.S. Lamhamedi, S. Carles, B. Fecteau, H.A. Margolis, M. Renaud, and P.Y. Bernier. 2010. Managing irrigation to reduce nutrient leaching in containerized white spruce seedling production. New For. 40:185-204.

Sylvia, D.M., J.J. Fuhrmann, P.G. Hartel, and D.A. Zuberer. 2005. Principles and applications of soil microbiology. Pearson, Prentice Hall, Upper Saddle River, NJ.

Tate, R.L. 2000. Soil microbiology. Wiley and Sons, Inc., New York, NY.

Taylor, L.L., A.X. Niemiera, R.D. Wright, and J.R. Harris. 2012. Storage time and amendments affect pine tree substrate properties and marigold growth. HortScience 47:1782-1788.

Vetanovetz, R. and J.C. Peterson. 1990. The fate of urea in a sphagnum peat medium as affected by lime source and rate. J. Amer. Soc. Hort. Sci. 115:386-389.

Walden, R.F. and R.D. Wright. 1995. Interactions of high temperature and exposure time influence nitrification in a pine bark medium. HortScience 30:1026-1028.

Woomer, P.L. 1994. Most probable number counts, p. 59-79. In: Weaver, R.W. (ed.). Methods of soil analysis. Part 2. Microbiological and biochemical properties. Soil Science Society of America, Inc., Madison, WI.

Wright, R. 1986. The pour-through nutrient extraction procedure. HortScience 21:227-229.

Wright, R.D. and J.F. Browder. 2005. Chipped pine logs: A potential substrate for greenhouse and nursery crops. HortScience 40:1513-1515.

Wright, R.D., B.E. Jackson, J.F. Browder, and J.G. Latimer. 2008. Growth of chrysanthemum in a pine tree substrate requires additional fertilizer. HortTechnology 18:111-115.

Yeager, T.H., D.C. Fare, J. Lea-Cox, J. Ruter, T.E. Bilderback, C.H. Gilliam, A.X. Niemiera, S.L. Warren, T.E. Whitwell, R.D. Wright, and K.M. Tilt. 2007. Best management practices: Guide for producing container-grown plants, Southern Nurserymen's Assoc, Marietta, GA. 